\title{
Analysis of Heavy Metal Contents in Water Toke District Kalat Balochistan, Pakistan by Using Atomic Absorption Spectrophotometer
}

\author{
Nazia Meer ${ }^{1}$, Masood Ahmed Siddiqui ${ }^{1}$, Afroz Rais ${ }^{2}$, Wenwu Qin ${ }^{3}$, Anam Iqbal ${ }^{1 *}$ and Kanwal \\ Iqbal $^{2 *}$ \\ ${ }^{1}$ Department of Chemistry, University of Baluchistan Quetta 87300, Pakistan \\ ${ }^{2}$ Department of Chemistry, Sardar Bahadur Khan Women's University Quetta 87300, Pakistan
}

${ }^{3}$ Key Laboratory of Nonferrous Metal Chemistry and Resources Utilization of Gansu Province and State Key Laboratory of Applied Organic Chemistry, College of Chemistry and Chemical Engineering, Lanzhou University, China

*Corresponding author: Anam Iqbal, Department of Chemistry, University of Baluchistan Quetta 87300, Pakistan

*Kanwal Iqbal, Department of Chemistry, Sardar Bahadur Khan Women’s University Quetta 87300, Pakistan

\section{ARTICLE INFO}

Received: 慧 August 15, 2020

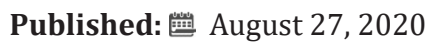

Citation: Nazia Meer, Masood Ahmed Siddiqui, Afroz Rais, Wenwu Qin, Anam Iqbal and Kanwal Iqbal. Analysis of Heavy Metal Contents in Water Toke District Kalat Balochistan, Pakistan by Using Atomic Absorption Spectrophotometer. Biomed J Sci \& Tech Res 29(5)-2020. BJSTR. MS.ID.004860.

\begin{abstract}
Herein for the first time the quantitative determination of seven heavy metal ions i.e., $\mathrm{Fe}, \mathrm{Cu}, \mathrm{Pb}, \mathrm{Cd}, \mathrm{Cr}, \mathrm{Mn}$ and $\mathrm{Zn}$ in the water samples of village Toke district Kalat Balochistan,

Pakistan have been carried out by using atomic absorption spectrophotometry. Calibrations were constructed for the seven metals using standard solution. The analysis showed that the concentrations of $\mathrm{Pb}, \mathrm{Cd}$ and $\mathrm{Cr}$ are moderately high in the water samples of determine the concentration of trace and heavy metals in drinking water of village Toke district Kalat Balochistan. Whereas $\mathrm{Zn}$ and $\mathrm{Cu}$ have no significant difference while, $\mathrm{Fe}, \mathrm{Cd}, \mathrm{Pb}$, and $\mathrm{Cr}$ have moderately high value compared to standard given by WHO.
\end{abstract}

Keywords: Heavy Metals; Kalat Balochistan; Atomic Absorption Spectrophotometric; Environment

\section{Introduction}

Water is the most important element for the living organisms without water it would be impossible to maintain life on earth [13]. Water pollution has become a very important field of global research due to the direct impact on climate and humans being [4-6]. Heavy metals are considered to be one of the main sources of pollution in the environment, since they have a significant effect on its ecological quality $[7,8]$. Human activity leads to increasing levels of heavy metal contamination in the environment. Heavy metals owing to atmospheric and industrial pollution accumulate in the water and influence the ecosystem nearby [9]. Surface water contamination with heavy metals is a serious environmental problem. The determination of heavy metal in water samples is very important in monitoring environmental pollution $[9,10]$.
Zinc (Zn), iron (Fe), manganese (Mn), copper ( $\mathrm{Cu}$ ), cadmium (Cd), Lead $(\mathrm{Pb})$ and chromium $(\mathrm{Cr})$ etc., were chosen as representative trace metals whose levels in the environment represent a reliable index of environmental pollution. Metals like zinc, iron, manganese, and copper are essential metals since they play an important role in biological systems, whereas $\mathrm{Pb}, \mathrm{Cr}$ and $\mathrm{Cd}$ are non-essential metals as they are toxic even in traces [11-13]. While the essential metals can also produce toxic effects when the metal intake is excessively elevated. Recently, both international and Pakistan studies have drawn attention to the metal pollution of water [1418]. But such a study has not been yet carried out in village Toke district Kalat which is back word area of Balochistan, Pakistan. Here water is mainly used by the people for drinking and agriculture purpose. Current study is almost first report on determination of 
trace and heavy metals in drinking and agriculture water of Toke Kalat, Balochistan. The aim of this study is to determine the mean concentrations of heavy metals including $\mathrm{Zn}, \mathrm{Fe}, \mathrm{Mn}, \mathrm{Cu}, \mathrm{Cd}, \mathrm{Pb}$, and $\mathrm{Cr}$ in water. Heavy metals concentrations were determined by Atomic Absorption Spectrometry (AAS). The relationships between the metal levels in samples collected from areas of the village and physicochemical parameters were assessed.

\section{Methods}

\section{Experimental}

Reagents and Solutions: Analar (AR grade) samples of Zn, Fe, $\mathrm{Mn}, \mathrm{Cu}, \mathrm{Cd}, \mathrm{Pb}$ and $\mathrm{Cr}$, Zinc Nitrate, Ferrous Sulphate, Manganese chloride, Copper Nitrate, Lead Nitrate, Chromium Chloride and Nitric acid, were purchased from Merck, Marker. All reagents are of Analar grade and triply distilled water were used throughout the study. The apparatus and the glassware's were thoroughly washed and dried in oven. Pre concentration of the samples were carried out and the residue was leached with $0.1 \mathrm{M} \mathrm{HNO}_{3}$ acid (Analar) solution. This solution was used for the determination of $\mathrm{Zn}, \mathrm{Fe}$, $\mathrm{Mn}, \mathrm{Cu}, \mathrm{Cd}, \mathrm{Pb}$ and $\mathrm{Cr}$ using Atomic Absorption Spectrophotometer (AAS).

\section{Instrumentation}

Elico SL 163 Atomic Absorption Spectrophotometer is used

Table 1: Name of sampling area with their symbols. to analyze the concentration of heavy metals with hollow cathode lamps of different metals and a flame of air-acetylene. The calibration curves were constructed using standard solution of the metal ions by following the procedure given in the manual using appropriate detectors in the wavelength range suitable for the concentration range. Five replicates of each experiment are carried out. The calibrations are precise and accurate as demonstrated by $\%$ RSD being less than 2 .

\section{Collection of Sample}

Five different water samples were collected from different areas of Toke Kalat district Table 1. To avoid possible contamination, these samples were collected in one liter capacity polypropylene bottles i.e. pre acid washed and then $0.5 \mathrm{~mL}$ of conc $\mathrm{HNO}_{3}$ were added to $75 \mathrm{~mL}$ of each sample I in order to avoid the microbial activities. The water samples were then boiled or evaporated up to one-fourth of original volume. The samples were then kept in a refrigerator for two weeks to stabilize the metals. From the pool $100 \mathrm{~mL}$ water sample was filtered and concentrated to about $60 \mathrm{~mL}$ in $100 \mathrm{~mL}$ standard flask to which $5.0 \mathrm{~mL}$ of conc. $\mathrm{HNO}_{3}$ was added. This was made up to the mark with de-ionized water. After digestion, samples were analyzed for $\mathrm{Zn}, \mathrm{Fe}, \mathrm{Mn}, \mathrm{Cu}, \mathrm{Cd}, \mathrm{Pb}$ and $\mathrm{Cr}$ using atomic absorption spectrophotometer according to standard methods as described in the manual supplied along with the atomic absorption spectrophotometer.

\begin{tabular}{|c|c|c|c|c|c|}
\hline Symbol & $\begin{array}{c}\text { Source of Tube well } \\
\text { water }\end{array}$ & Symbol & $\begin{array}{c}\text { Source of drainage } \\
\text { water }\end{array}$ & $\begin{array}{c}\text { Source of Storage } \\
\text { water }\end{array}$ & Koshi \\
\hline TW1 & Koshi & DW1 & Koshi & SW1 & KWnd \\
\hline TW2 & Kund & DW2 & Kund & SW3 & Kukri \\
\hline TW3 & Kukri & DW3 & Kukri & SW4 & Main village \\
\hline TW4 & Main village & DW4 & Main village & KW5 & Kooki \\
\hline TW5 & Kooki & DW5 & Kooki & SW5 \\
\hline
\end{tabular}

\section{Results and Discussion}

The analysis of water from the study area showed that water samples have no color and odor. The analytical results of metals in the samples of water are shown in the Table 2. This data showed that the concentration of $\mathrm{Fe}, \mathrm{Cd}, \mathrm{Cr} \mathrm{Zn}, \mathrm{Mn}$, and $\mathrm{Pb}$, are found to be present moderately high in the samples of Toke kalat district, where as $\mathrm{Cu}$, and $\mathrm{Cr}$ concentration in all the study areas had no significant difference of concentrations when compared with WHO data. The table shows the results of analysis together with the permissible range of metal ions as defined by WHO. After analysis, the obtained results ( $\mathrm{ppm}_{-1}$ ) for $\mathrm{Zn}, \mathrm{Fe}, \mathrm{Cd}, \mathrm{Mn}, \mathrm{Cu}, \mathrm{Pb}$, and $\mathrm{Cr}$ are shown in Table 2.

Table 2: Concentration (ppm L-1) various elements in selected medicinal plants.

\begin{tabular}{|c|c|c|c|c|c|c|c|}
\hline \multirow{2}{*}{ S.No } & \multirow{2}{*}{ Metals } & \multicolumn{7}{|c|}{ Concentration found in ppm L } & $\begin{array}{c}\text { Permissible conc of WHO } \\
\text { in ppm }\end{array}$ \\
\hline \multirow{2}{*}{1} & \multirow{2}{*}{$\mathrm{Fe}$} & Tube well-I & Tube well-2 & Drainage water 1 & $\begin{array}{c}\text { Drainage water } \\
2\end{array}$ & $\begin{array}{c}\text { Stored water } \\
\text { sources }\end{array}$ & \multirow{2}{*}{0.2} \\
\cline { 3 - 8 } & & $0.5 \pm 0.02$ & $0.4 \pm 0.02$ & $0.4 \pm 0.02$ & $0.4 \pm 0.02$ & $0.3 \pm 0.02$ & \\
\hline 2 & $\mathrm{Cd}$ & $0.005 \pm 0.02$ & $0.003 \pm 0.02$ & $0.004 \pm 0.02$ & $0.004 \pm 0.02$ & $0.004 \pm 0.02$ & 0.003 \\
\hline 3 & $\mathrm{Cr}$ & $0.05 \pm 0.02$ & $0.06 \pm 0.02$ & $0.07 \pm 0.02$ & $0.06 \pm 0.02$ & $0.06 \pm 0.02$ & 0.05 \\
\hline 4 & $\mathrm{~Pb}$ & $0.04 \pm 0.02$ & $0.05 \pm 0.02$ & $0.03 \pm 0.02$ & $0.04 \pm 0.02$ & $0.05 \pm 0.02$ & 0.01 \\
\hline 5 & $\mathrm{Cu}$ & $2.3 \pm 0.02$ & $2.02 \pm 0.02$ & $1.9 \pm 0.02$ & $2.2 \pm 0.02$ & $2.01 \pm 0.02$ & 2.00 \\
\hline 6 & $\mathrm{Zn}$ & $3.1 \pm 0.02$ & $3.9 \pm 0.02$ & $4.1 \pm 0.02$ & $3.9 \pm 0.02$ & $3.00 \pm 0.02$ & \\
\hline 7 & $\mathrm{Mn}$ & $0.6 \pm 0.02$ & $0.54 \pm 0.02$ & $0.56 \pm 0.02$ & $0.58 \pm 0.02$ & $0.58 \pm 0.02$ & 3.00 \\
\hline
\end{tabular}




\section{Conclusion}

The presence of heavy metals with moderate high concentrations in the water samples of Toke Kalat district indicates that there can be a chance of damage 9 to water and animal kingdom including human beings. Hence continual assessment and enlightenment is highly essential.

\section{Conflict of Interest}

There are no conflicts to declare.

\section{References}

1. Mustafa S, N Baloch, S Muhammad, Y Malik, T Khan (2017) Determination of trace and heavy metals in drinking water of Jhal Magsi district of Balochistan Pakistan. Pure Applied Biology 6(1): 9.

2. Hussain J, J Shah, I Khan, D Lopes, R Souza, (2012) Determination of trace elements in the drinking water of mardan district KPK Pakistan. EurasiaJ Agre Environ Sci 12: 1091-1094.

3. Kulkarni S, S Dhokpande, J Kaware (2015) A Review On Spectrophotometric Determination Of Heavy Metals With Emphasis On Cadmium And Nickel Determination By UV Spectrophotometry. Int J Adv Eng Res Sci 2: 34-36.

4. Ezemonye L, A Enuneku (2005) Evaluation of acute toxicity of cadmium and lead to amphibian tadpoles (Toad: Bufo maculatus and frog: Ptychadena bibroni) Journal of aquatic Sciences 20: 33-38.

5. Kulkarni S J, S R Dhokpande, D J P Kaware ( 2013) Studies on flyash as an adsorbent for removal of various pollutants from wastewater. Int J Eng Res Technol 2(5): 1190-1195.

6. Kulkarni S J (2013) Removal of organic matter from domestic waste water by adsorption. Int J Sci Eng Technol Res 2(10): 1836-1839.

7. Sastre J, A Sahuquillo, M Vidal, G Rauret (2002) Determination of Cd, Cu, $\mathrm{Pb}$ and $\mathrm{Zn}$ in environmental samples: microwave-assisted total digestion versus aqua regia and nitric acid extraction. Analytica Chimica Acta

\section{ISSN: 2574-1241}

DOI: $10.26717 /$ BJSTR.2020.29.004860

Anam Iqbal, Kanwal Iqbal. Biomed J Sci \& Tech Res

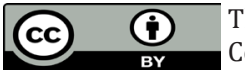

This work is licensed under Creative Commons Attribution 4.0 License

Submission Link: https://biomedres.us/submit-manuscript.php
462(1): 59-72.

8. Kulkarni S J, S R Dhokpande, D J P Kaware (2014) A Review on Studies on Effect of Heavy Metals on Man and Environment. Int J Res Appl Sci Engi Technol 2: 227-229.

9. Al Radady, A B Davies, M French (1994) Distribution of lead inside the home: case studies in the North of England. Sci Envt 145: 143-156.

10. Zhou C, M Wong, L Koh, Y Wee (1997) Soil lead and other metal levels in industrial, residential and nature reserve areas in Singapore. Environl Monit Assesst 44: 605-615.

11. Nahid P, Y Rohan (2011) Spectrophotometric determination of some environmental samples. J Envi Res Devel 6(1): 57-62.

12. Sarker K C, R Ullaha (2013) Determination of Trace Amount of Cu (II) Using UV-Vis Spectrophotometric Method. Int J Chem Studie 1: 5-14.

13. Heghedūş-Mîndru, R C Heghedūş-Mîndru, P Negrea, D S Ștef, R L Şumălan et al. (2013) Quantitative determination by atomic absorption spectrometry for macro elements of mineral waters from Romania. Revi Agri Rural Devel 2: 245-251.

14. Soylak M, O Türkoglu (1999) Trace metal accumulation caused by traffic in an agricultural soil near a motorway in Kayseri Turkey. J Trace Microprobe Tech 17: 209-217.

15. Beck J N, J Sneddon (2000) Metal concentrations in soils and sediments in Southwest Louisiana. Anal. Lett.

16. Tüzen M (2003) Determination of heavy metals in soil, mushroom and plant samples by atomic absorption spectrometry. Microchem J 74(3): 289-297.

17. Ahmad M, S Muhammed, N Jahan, S U Jan, Qureshi (2014) Anti-dermatitis, anxiolytic and analgesic effects of Rhazya stricta from Balochistan. Pak J Pharma Sci 27(3): 45-48.

18. Kawatra B, P Bakhetia (2008) Consumption of heavy metal and minerals by adult women through food in sewage and tube-well irrigated area around Ludhiana city (Punjab, India). J Human Ecol 23(4): 351-354.

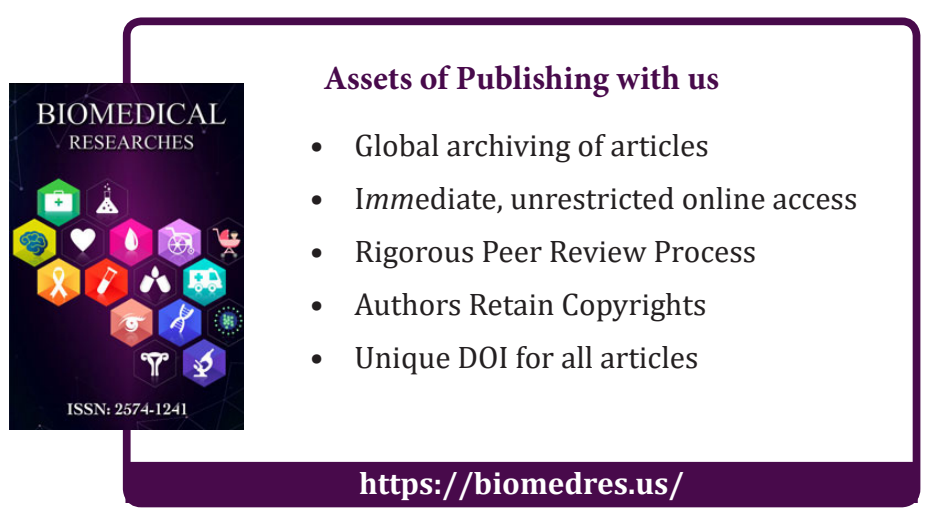

